\title{
QUANTITATIVE DYNAMICS AND PHYTODIVERSITY OF UNDERGROWTH IN FORESTS OF BANGLADESH
}

\author{
M. A. M. CHOWDHURY* and M. K. HUDA \\ Department of Botany, University of Chittagong, Chittagong - 4331, Bangladesh
}

\begin{abstract}
Proceedings of the South and Central Asian MAB Meeting of Experts on Environmental Conservation, Management and Research, Hikkaduwa, Sri Lanka 15-18 October 2002
\end{abstract}

\begin{abstract}
Summary: Phytodiversity of the undergrowth in six forests of Bangladesh was studied in 4 seasons by the random quadrat method during the years 1998-2000. A total of 445 undergrowth species belonging to 82 families were recorded. Of these, 69 families belonged to dicotyledons, 10 to monocotyledons, 3 were pteridophytes, and the 17 others are still unidentified. Maximum number of undergrowth species was found in Fabaceae, Euphorbiaceae, Moraceae, Vitaceae, Rubiaceae, Asteraceae, Apocynaceae and Verbenaceae of dicot and Zingiberaceae, Araceae, Orchidaceae and Poaceae of monocot. Importance value per cent of all species were determined and the values ranged from 0.016 to 6.32 . Twenty-six species were found to be dominant on the basis of importance value per cent that ranged from 3.02 to 6.32. Percentages of various habit forms of undergrowth such as ferns -1.5 , sedges -2.2 , grasses -3.5 , climbers -9.2 , herbs -35.5 , undershrubs -16.8 , shrubs -10.2 , small trees -13.3 , and large trees -7.7 , were determined. Similarly, per cent of Raunkaier's life form spectrum such as succulent - 0.94, epiphytes - 2.1, Mega-mesophaenerophytes 14.5 , microphaenerophytes -29.9 , nanophaenerophytes -30.4 , chamephytes -8.7 , hemicryptophytes 8.7 , geophytes -1.4 , therophytes -1.4 , and hydro-helophytes -1.4 were also determined. Most undergrowth species were found to grow luxuriantly during April-September. Dynamics of species diversity of undergrowth of six forests were determined using Shannon-Wiener species diversity function and Simpson diversity index. Species diversity $(\mathrm{H})$ of undergrowth, along with maximum diversity $\left(\mathrm{H}_{\max }\right)$, equitability $(\mathrm{E})$ and species diversity index $(D)$ of all forests were found in the maximum range of $6.071,7.150,0.903$ and 0.979 , respectively. It is concluded that the calculated value of components of species diversity of all protected, reserves and unclassified state forests coming within the study area, did markedly change even though these forests were different in their physiognomy and structure.
\end{abstract}

Key Words: Forest, undergrowth, habit form, life form, species diversity, genepool

\section{Introduction}

Bangladesh is a forest poor country although it looks lush green. The forest cover has shrunk to merely six per cent of the land area today from twenty per cent in 1927. This has several serious consequences for the local environment and the forest dwelling communities. About 8,461 sq. miles of land is forest, consisting of khasland, reserve forest, acquired forest, vested forest, protected forest and unclassified state forest. Generally, three types of forests, namely tropical evergreen or semi evergreen,

" Corresponding author 
moist or dry deciduous and tidal mangrove forests are under the management system of the Forest Department of Bangladesh at present. ${ }^{5}$ Forest species have long been disturbed both biotically and abiotically in most forest areas of Bangladesh. This has resulted in changing the naturally growing undergrowth. Undergrowth vegetation of natural reserved, protected and unclassified state forests has an important role to play in the protection of natural forest as well as existing plant diversity. Vegetative cover plays a vital role in controlling soil erosion, increasing soil fertility, nutrient cycling, natural regeneration as well as providing an abode for wildlife. It also acts as a genetic resources-gene pool of wild or domesticated species and as such provides medicinal plants, fodder, forage, and green manure, while also helping in soil covering, soil binding and regeneration. Wild animals mostly use the undergrowth as food, fodder and shelter.

Quantitative inventories of the floristic composition, life form, habit form, species diversity, maximum diversity, equitability and species diversity index of undergrowth have not been made for these forest areas of Bangladesh. This paper aims at making an extensive inventory of the undergrowth flora, habit form, life form, species diversity and thus provide a check list of undergrowths for further analyses of six forests of Bangladesh. Taxonomy of undergrowth flora and their corresponding importance value per cent is in progress for separate publication.

\section{Methods and Materials}

Study areas: The study areas $\left(20^{\circ} 41^{\prime}-20^{\circ} 44^{\prime} \mathrm{N}, 92^{\circ} 4^{\prime}-92^{\circ} 6^{\prime} \mathrm{E}\right)$ are situated in the eastern part of Bangladesh and consists of the Dulahazara Garjan Forest - a Protected Forest (PF), Kaptai Sita-Pahar Mixed Forest - a Natural Reserve Forest (NRF), Rauzan Teak Forest - a Protected Forest (PF), Akashmani Forest of Chittagong University Campus - (PF) and Sitakunda Scrub Forest - a Protected Forest (PF). Besides these, the Sal Forest of Gazipur - a Protected Forest (PF) has also been included in this study. All these forests, except for the Kaptai Sita-Pahar Reserve Forest, are located at an elevation of $50-80 \mathrm{~m}$ above sea level. The Kaptai Sita-Pahar Reserve Forest which comprises high hills is located about $300 \mathrm{~m}$ above sea level. The average annual rainfall in this area is about $350 \mathrm{~cm}$ and most of it occurs between May and September. The mean annual temperature is about $25^{\circ} \mathrm{C}$ with mean monthly temperature varying from $16^{\circ} \mathrm{C}$ (January) to $33^{\circ} \mathrm{C}$ (May). The topography is rugged and the terrain in hilly areas is extremely irregular. The soil varies from sandy loam to loam in hilly ground. The soil is often impregnated with iron, giving it a reddish or yellowish tinge. The soil is very porous and sandy in these areas. ${ }^{4}$

Selection of sites: Three sites in each forest were selected, with each site consisting of three stands. Three stands were randomly selected using CRD method from the laid grid of vegetation. The vegetation of 9 stands of each site in each forest generally varied considerably in physiognomy but not much in quality as found from the 
extensive survey made at three month intervals during two years. Most of the sites studied were found to be biotically disturbed.

Collection, processing and analysis of soil: Soil samples were collected randomly from the topsoil $(1-25 \mathrm{~cm})$ and sub-soil $(26-50 \mathrm{~cm})$ at three places in each stand. The three samples from each stand were mixed together to form a replicate and used as a composite sample. The soil moisture content of each composite sample was determined gravimetrically. Then the soil samples were dried in the open air and ground before storage. The samples were passed through a $2 \mathrm{~mm}$ sieve. The sieved soil samples were then stored in a cool dry place in the laboratory for further analysis of soil texture, $\mathrm{pH}$, electrical conductivity (EC), organic matter (OM), cation exchange capacity (CEC), Nitrogen (N), Phosphorus (P), Potassium (P), Calcium (Ca), Magnesium (Mg), Manganese (Mn) and Iron (Fe). Soil texture was determined using the Bouycous Hydrometer Method and named according to the soil texture-class triangle. ${ }^{11}$ Soil $\mathrm{pH}$ and electrical conductivity were measured in a 1:2 soil/water suspension using a calibrated $\mathrm{pH}$ meter and conductivity meter respectively. Organic matter content was determined by the modified Oxidation Method of Walkley and Black. ${ }^{12}$ The total nitrogen of soil was extracted with a mixed catalyst $\left(\mathrm{H}_{2} \mathrm{SO}_{4}-\mathrm{CuSO}_{4}\right)$, and determined using the Micro-Kjeldahl Distillation Method. ${ }^{6}$ Cation exchange capacity was determined in a $1 \mathrm{M} \mathrm{KCl}$ soil extract. Available phosphorous was extracted using $1 \mathrm{M}$ ammonium acetate $(\mathrm{pH} 7.0 \pm 0.1)$ and determined using the Spectrophotometer Method. Available potassium, calcium, magnesium, manganese and iron were extracted using $1 \mathrm{M}$ ammonium acetate ( $\mathrm{pH} 7.0 \pm 0.1$ ). Potassium and calcium were measured using the Flame Photometer and magnesium, manganese and iron were determined using the Atomic Absorption Spectrophotometer.

Collection, processing and analysis of undergrowth: The undergrowth plant species of different stands, sites and forests were observed, recorded and collected round the year at 3 month intervals during four sampling times - January, March, June and September. These times can be called the winter, early monsoon, monsoon and late monsoon periods respectively. The sample plot size $(4 \mathrm{~m} \mathrm{x} 4 \mathrm{~m}, 5 \mathrm{~m}$ x $5 \mathrm{~m}$ or $6 \mathrm{~m} \mathrm{x}$ $6 \mathrm{~m}$ ) was determined for the different forest sites by using the Species Area Curve Method. Samples from each plant species were recorded, counted and collected for proper identification, and phytosociological analysis. The quantitative phytosociological attributes such as density (D), relative density (RD) frequency $(\mathrm{F})$, relative frequency $(\mathrm{RF})$, abundance (A) relative abundance (RA) were analyzed and importance value per cent (IV\%) of all undergrowth species were computed by $\mathrm{RD}+\mathrm{RF}+\mathrm{RA} / 3 .^{3}$ The determination of habit form of undergrowth species were done according to the field reports of authors during the survey period. The determination of life form/biological spectrum was determined according to Raunkaier's ${ }^{9}$ life form system. The recorded species were identified and classified according to Hutchison's system of classification. 
The species diversity of undergrowths of different forests was calculated with the use of Shannon-Wiener species diversity function, which is as follows:

$$
\mathrm{H}=\sum_{\mathrm{i}=1}^{\mathrm{S}}(\mathrm{pi})\left(\log _{\mathrm{e}} \mathrm{pi}\right)(\mathrm{Krebs}, 1972)
$$

Where, $\mathrm{H}=$ Diversity index; $\mathrm{Pi}=$ Proportion of total sample belonging to the $\mathrm{i}$ th species, $\mathrm{S}=$ number of species.

Two components are combined in the Shannon-Wiener function viz., I) number of species and II) equitability. ${ }^{8}$ Where equitability can be measured as:

$\mathrm{E}=\mathrm{H} / \mathrm{H}_{\max }$, (where, $\mathrm{E}=$ equitability (range $0-1$ ), $\mathrm{H}=$ observed species diversity and $\mathrm{H}_{\max }=$ maximum species diversity). $\mathrm{H}_{\max }$ can be defined as $\mathrm{H}_{\max }=\mathrm{S}\left(1 / \mathrm{S} \log _{2} 1 / \mathrm{S}\right)$ $=\log _{2} \mathrm{~S}$, where $\mathrm{S}=$ number of species in the community. Diversity of species can also be measured using the probability theory as recommended by Simpson (1949), which is as follows:

$\mathrm{D}=1-\Sigma(\mathrm{Pi})^{2}$, where, $\mathrm{D}=$ Simpson's index of species diversity, $\mathrm{Pi}=$ Proportion of species " $\mathrm{i}$ " in the community.

\section{Results and Discussion}

Climatic factors such as rainfall, temperature and relative humidity of six forests are shown in Figure 1. The results reveal that rainfall ranged from $2 \mathrm{~cm}$ to $46 \mathrm{~cm}$. Maximum rainfall was recorded during July-August and the minimum in DecemberJanuary. Average temperature (maximum and minimum) in general ranged from $16^{\circ} \mathrm{C}$ to $33^{\circ} \mathrm{C}$. The maximum temperature was recorded in June-July and the minimum in December-January. Similarly, the average relative humidity ranged from $70-92 \%$. The results of Figure 2 indicate that the maximum relative humidity was observed in July-August and the minimum in December-January. Total annual rainfall ranged from $320-350 \mathrm{~cm}$ in the forest areas. Light penetration in the forest floor varied with the density and canopy cover of forest species.

Physico-chemical features of the forests which were studied are shown in Table 2. The results indicate that the moisture content of the forest floor ranged from $14.29 \%$ to $23.76 \%$ with an average of $19.97 \%$. Soil texture varied from loamy sand to sandy clay loam, and was generalized as a sandy loam. Organic matter content ranged from $0.65 \%$ to $1.27 \%$ and an average of $1.22 \%$ was determined for all forests. $\mathrm{pH}$ value of soil ranged from 4.43 to 6.29 and an average of 5.26 was determined. Electrical conductivity varied from 190 to $313 \mu \mathrm{S} \mathrm{cm}^{-1}$ and an average of $239 \mu \mathrm{S} \mathrm{cm}^{-1}$ was determined for all forests. CEC ranged from 0.028 to $0.165 \mathrm{meq}$ $\mathrm{g}^{-1}$ and an average of $0.098 \mathrm{meq} \mathrm{g}^{-1}$ was determined. Total nitrogen varied and ranged from 0.533 to $1,118 \mu \mathrm{gg}^{-1}$, and an average of $752 \mu \mathrm{gg}^{-1}$ was determined. Available 
nutrients such as $\mathrm{P}, \mathrm{K}, \mathrm{Ca}, \mathrm{Na}, \mathrm{Mg}, \mathrm{Mn}$ and Fe varied and ranged from 3 to $10 \mu \mathrm{gg}$ 1, 32 to $186 \mu \mathrm{gg}^{-1}, 26$ to $115 \mu \mathrm{gg}^{-1}, 50$ to $213 \mu \mathrm{gg}^{-1}, 49$ to $77 \mu \mathrm{gg}^{-1}, 9$ to $69 \mu \mathrm{gg}^{-1}$ and 0.9 to $1.6 \mu^{-1}$ respectively.

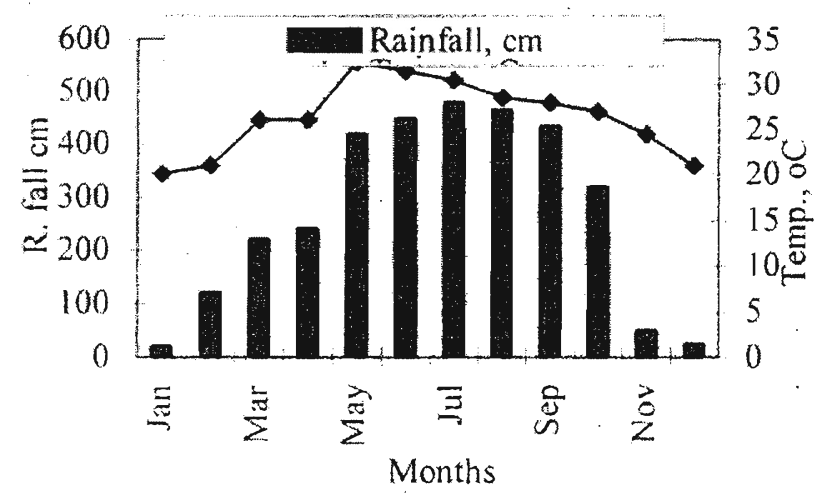

Figure 1: Average Rainfall and Temperature in the Forests of Bangladesh which came Within the Study Area

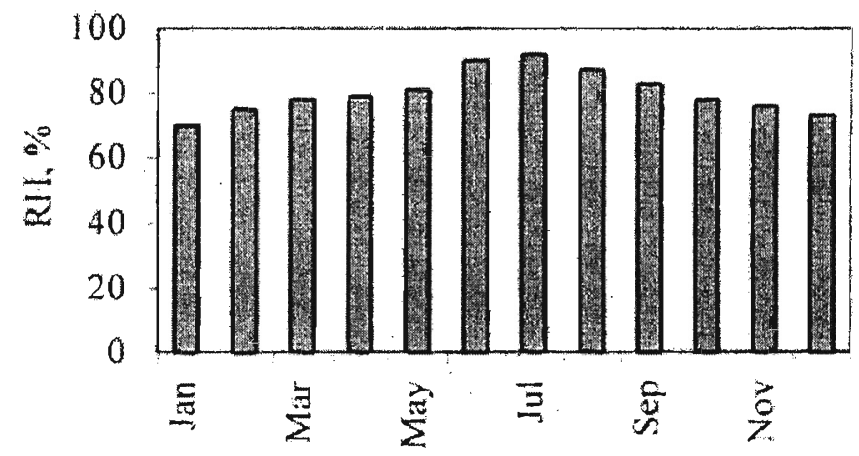

Figure 2: Average Relative Humidity in Forests of Bangladesh which came Within the Study Area

Habit form and life form of undergrowth species of six forests which varied in nature were determined and are presented in Tables 2 and 3. The results in Table 2 reveal that habit form of undergrowth varied from forest to forest both in number as well as in habit form. Habit form of undergrowth of all forests consisted of ferns, sedges, grasses, climbers, herbs, under shrubs, shrubs, small trees and large trees. A total of 428 undergrowth spcies were identified from six forests. The distribution in number and percentage of these 428 are shown in Table 2 and ranked in decreasing order as herbs-35.3\%> undershrubs-16.8\%> small trees-13.3\%> shrubs $-10.2 \%>$ climbers $-9.2 \%>$ large trees $-7.7 \%>$ grasses $-3.5 \%>$ sedges $-2.2 \%>$ and ferns-1.5\%. Average number and percentage distribution of undergrowth also reveal that in most of the forests it is still dominated by herbs $>$ shrubs $>$ and trees. 


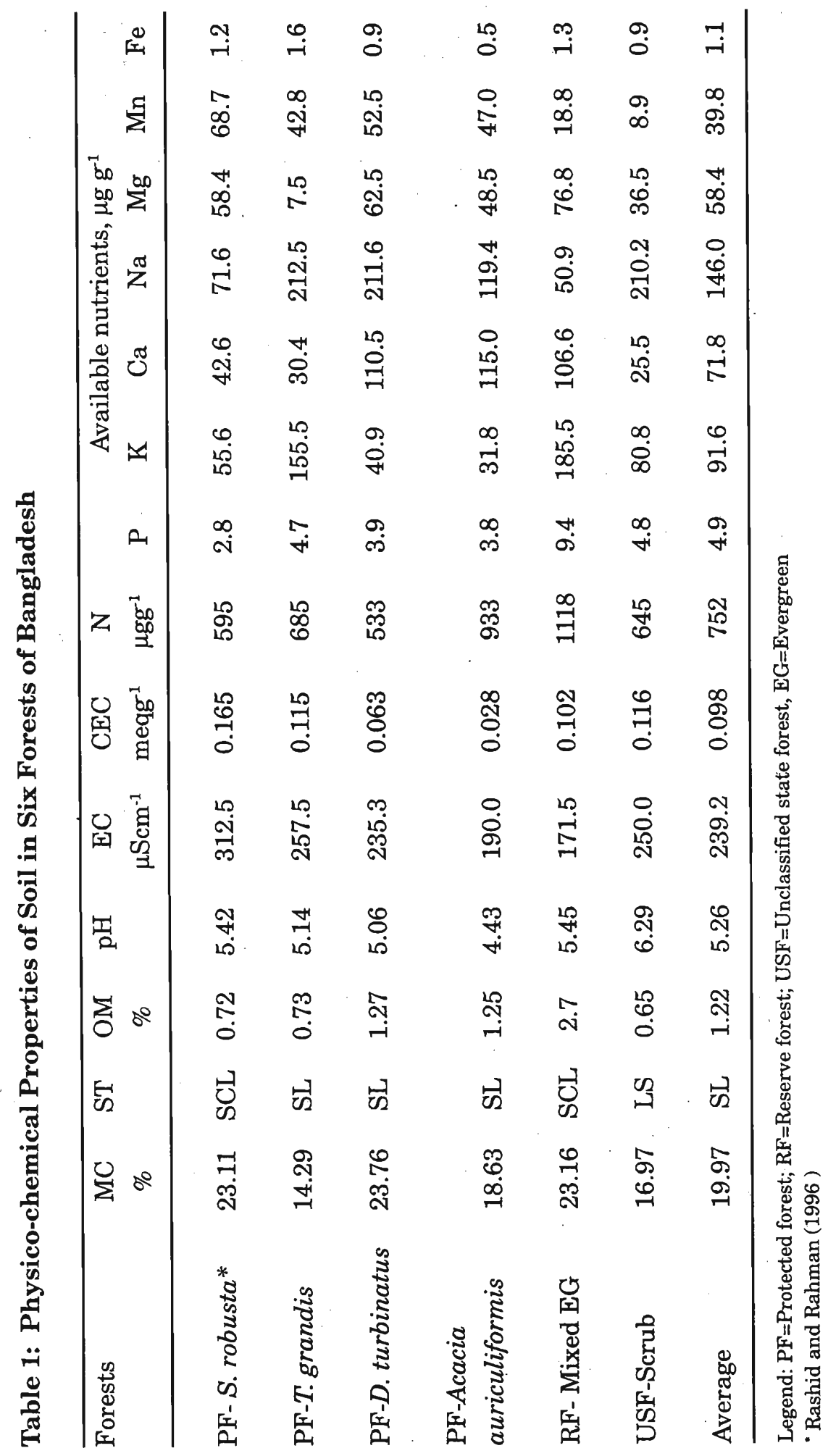




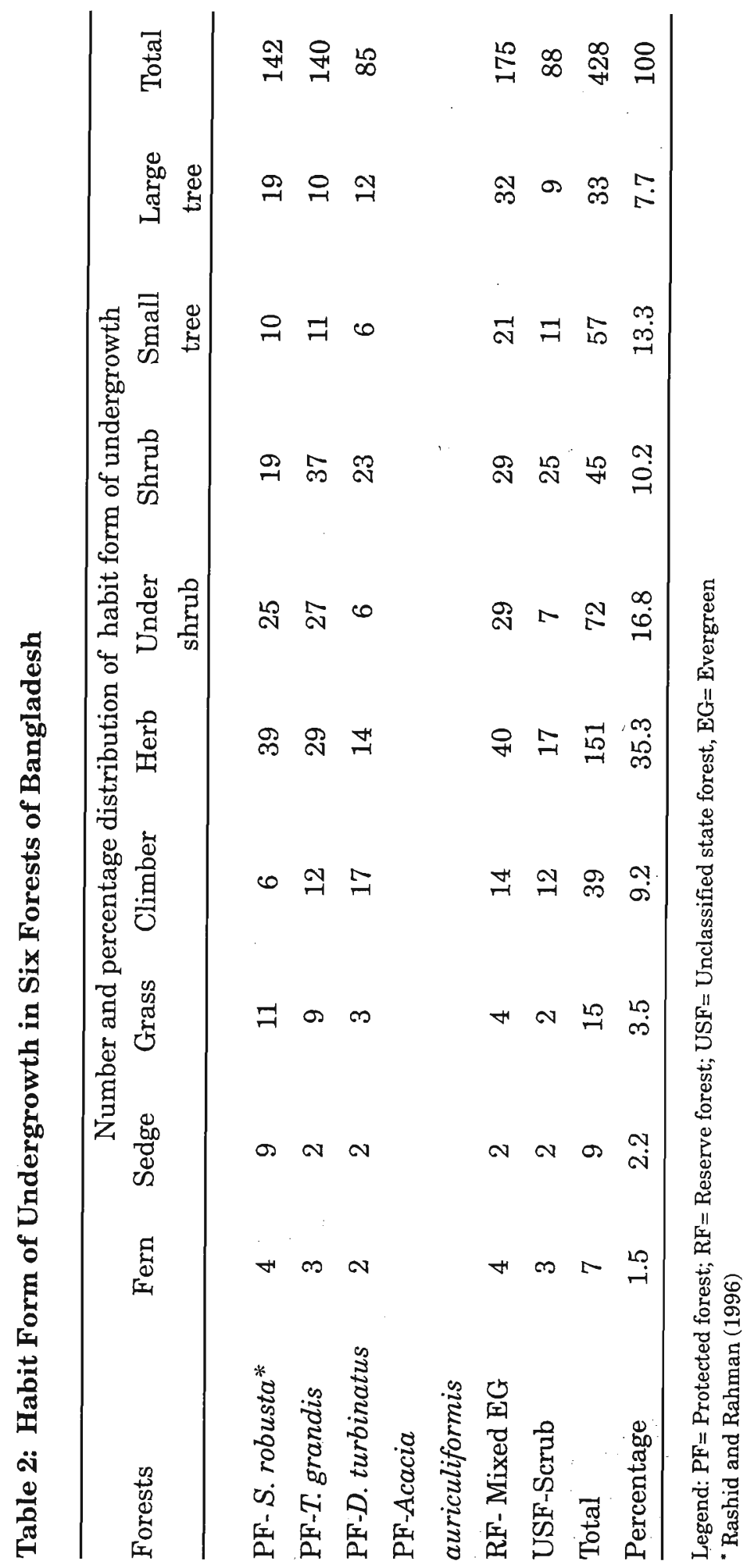




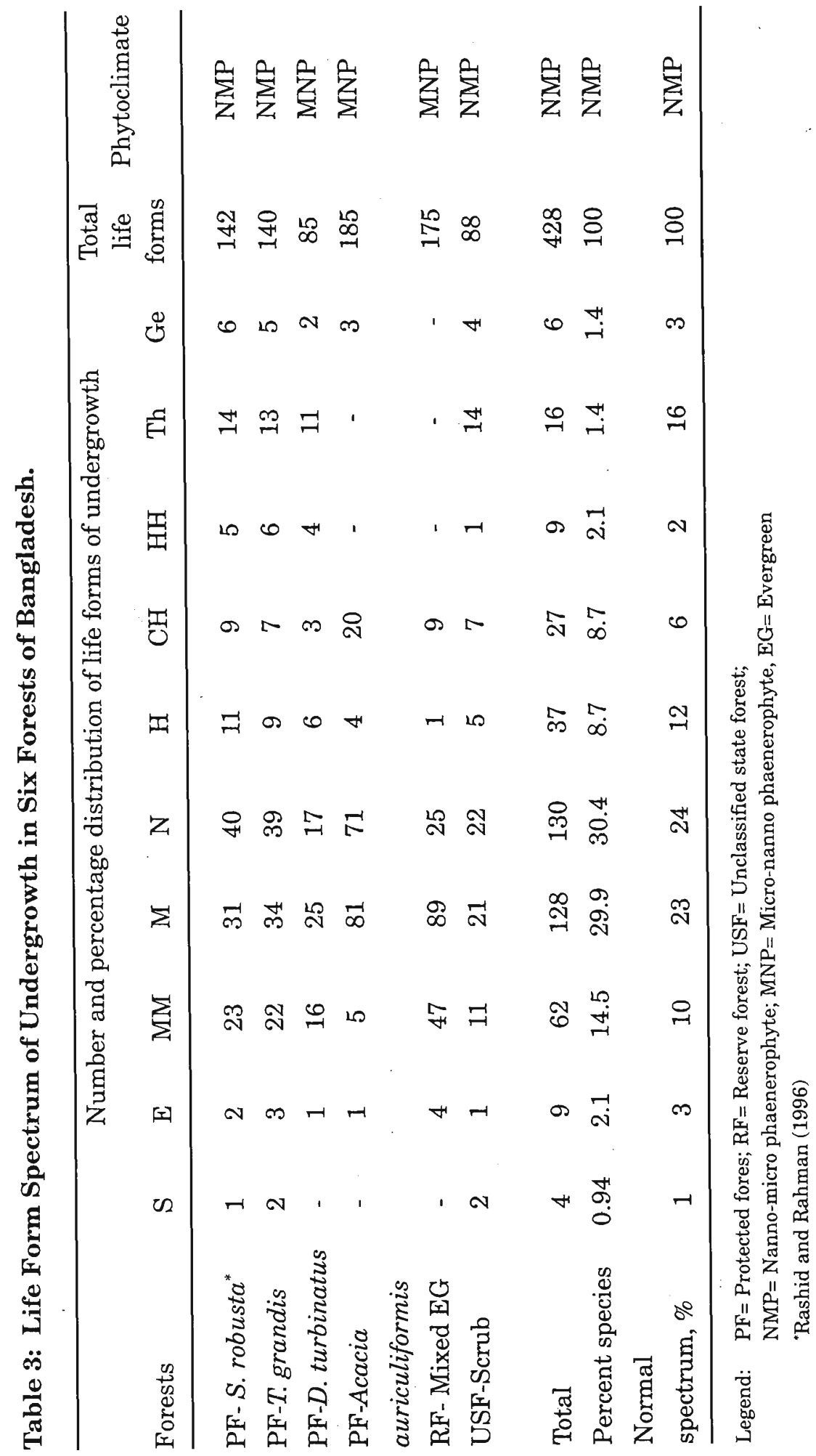




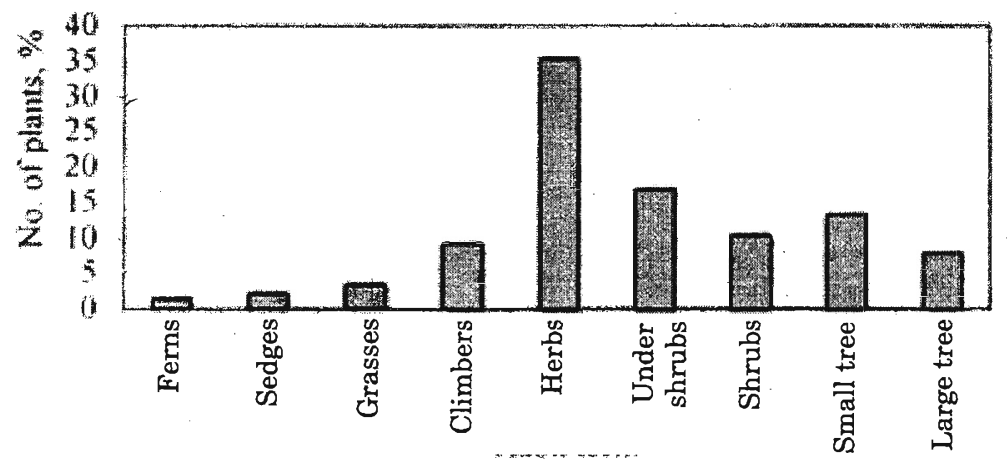

Figure 3: Habit Form of Undergrowth in Forests of Bangladesh

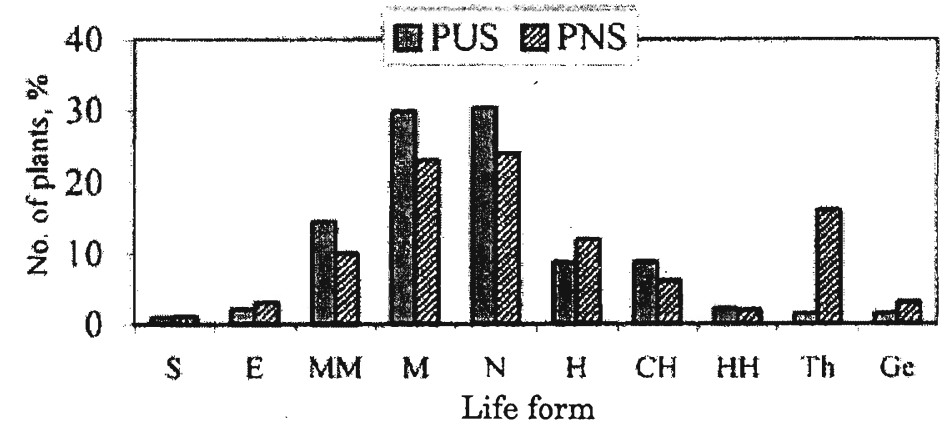

Figure 4: Comparison Between Life Form of Undergrowths of Bangladesh Forests and Raunkaier's Normal Life Form of Tropical Forests

The results in Table 3 indicate that the life form of the undergrowth of six forests varied in number and percentage and were usually dominated by two types of phytoclimate such as nano-microphaenerophytes and micro-nanophaenerophytic. It is clear that all different life forms were not observed in all forests. The number and percentage distribution of all Raunkaier's life forms can be ranked in decreasing order as nano-phaenerophytes-31\%> micro-phaenerophytes-30\%>therophytes$16 \%>$ mesophaenerophytes $-15 \%>$ chamephytes $-9 \%>$ hemicryptophytes-6\%> geophytes-3\%> epiphytes-3\%> hydrophytes and helophytes-2\%> and succulent$1 \%$. It is evident that Raunikaier' ${ }^{9}$ normal life form spectrum of tropical forest is not seen in the life form spectrum of undergrowth of the forests of Bangladesh which come within this study. A detailed study of all forests may fit well with Raunkaier's life form. Of course the present study reveals that the phytoclimate of the studied forests was termed nano-microphaenerophytes which is somewhat similar to that of Raunkaier's proposal of phytoclimate. It is also clear that the diversity of undergrowth species in these forests was not uniform since the forests were mainly biotically disturbed. 


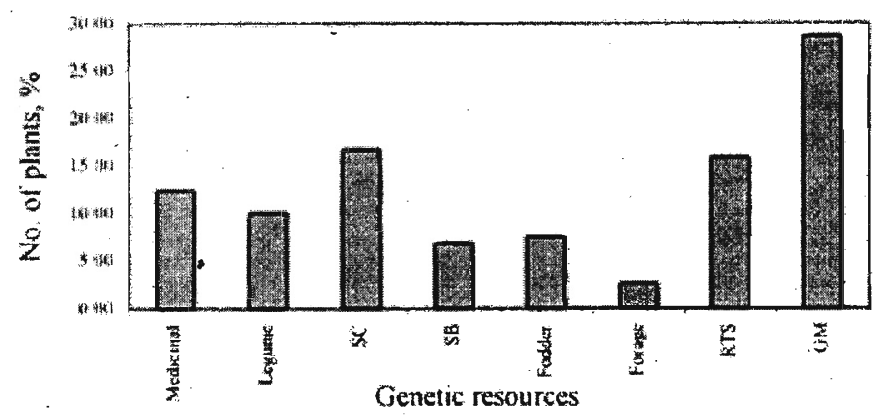

Figure 5: Genetic Resource-Gene Pool of Undergrowth in Studied Forests of Bangladesh which come Within the Study Area.

( $\mathrm{SC}=$ Soil covering; $\mathrm{SB}=$ Soil binder; $\mathrm{RTS}=$ Regenerated tree seediling; $\mathrm{GM}=$ Green manure)

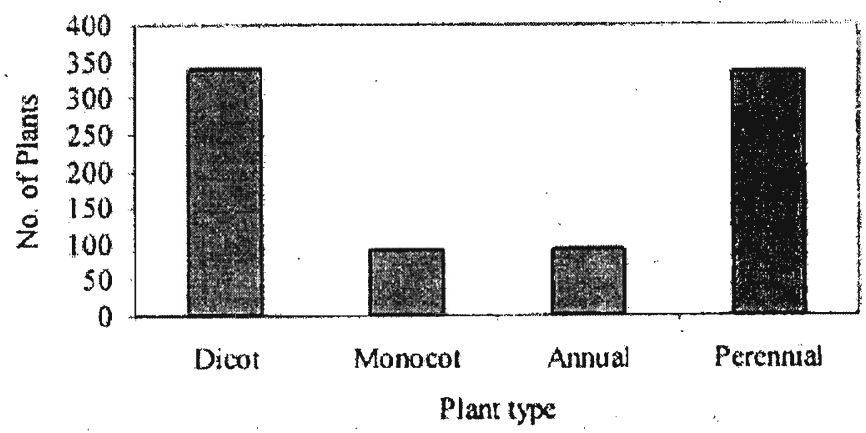

Figure 6: Number of Plant Types Available in Six Forests of Bangladesh

The number and percentage distribution of dicots-monocots and annualsperennials are shown in Table 4 . The results, indicate that dicots and monocots were present in the ratio of $9: 1$, whereas annuals and perennials were present in the ratio of almost 1:9. The number and percentage distribution of genetic resources of undergrowth as medicinal, legumes, soil covering, soil binding, fodder, forage, regenerated tree seedlings and green manures were in the ratio of $12.38: 10.04$ : $16.55: 6.78: 7.48: 2.57: 15.65$ and 28.50 respectively. All undergrowth were observed to grow luxuriantly in monsoon and late monsoon periods. Of course the number and growth of undergrowth species varied with seasons and sites of forests.

Dynamics and diversity of undergrowth of six protected reserve forests are shown in Table 5. The results, reveal that the number of families, genera and species varied with forest types. A total of 82 families were recorded, consisting of 266 genera and 428 species. Analysis of data also reveal that the importance value per cent of undergrowth species varied from 0.016 to 6.32 , and among the dicotyledons Fabaceae, Euphorbiaceae, Scrophulariaceae and Convolvulaceae were found to contain the maximum number of species in the undergrowth. In monocots, the number of undergrowth species were maximum in Poaceae, Cyperaceae, 


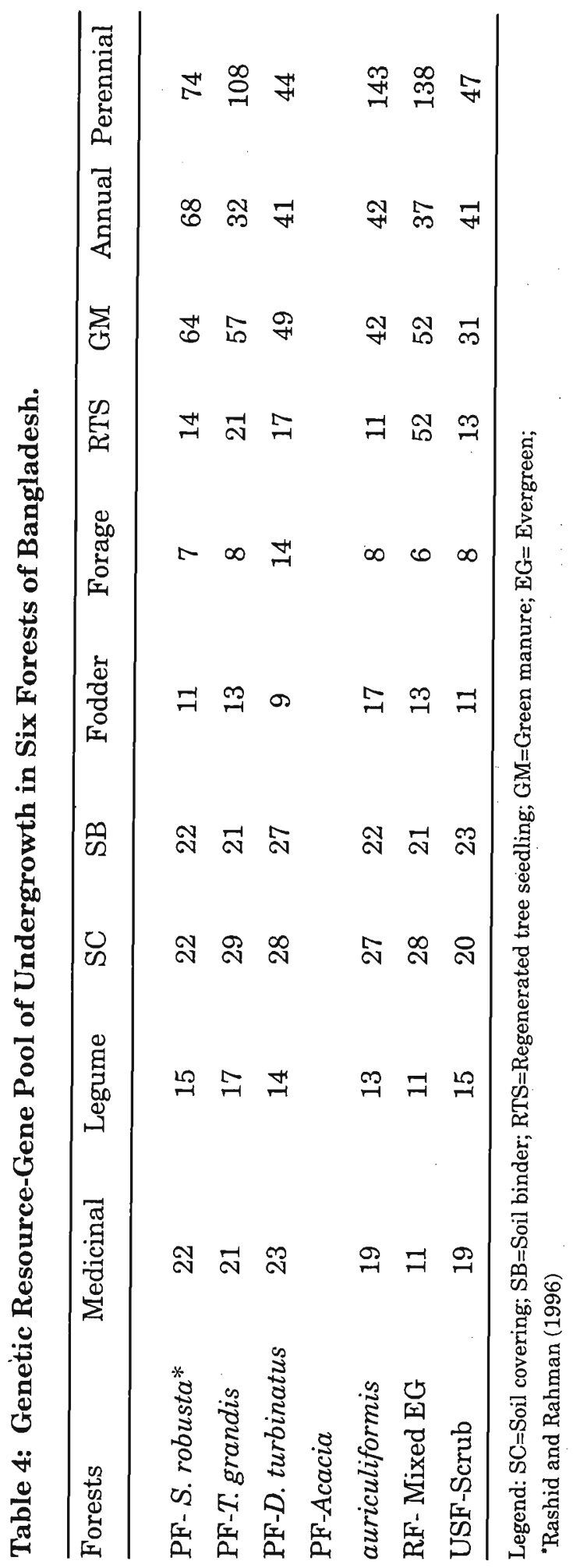




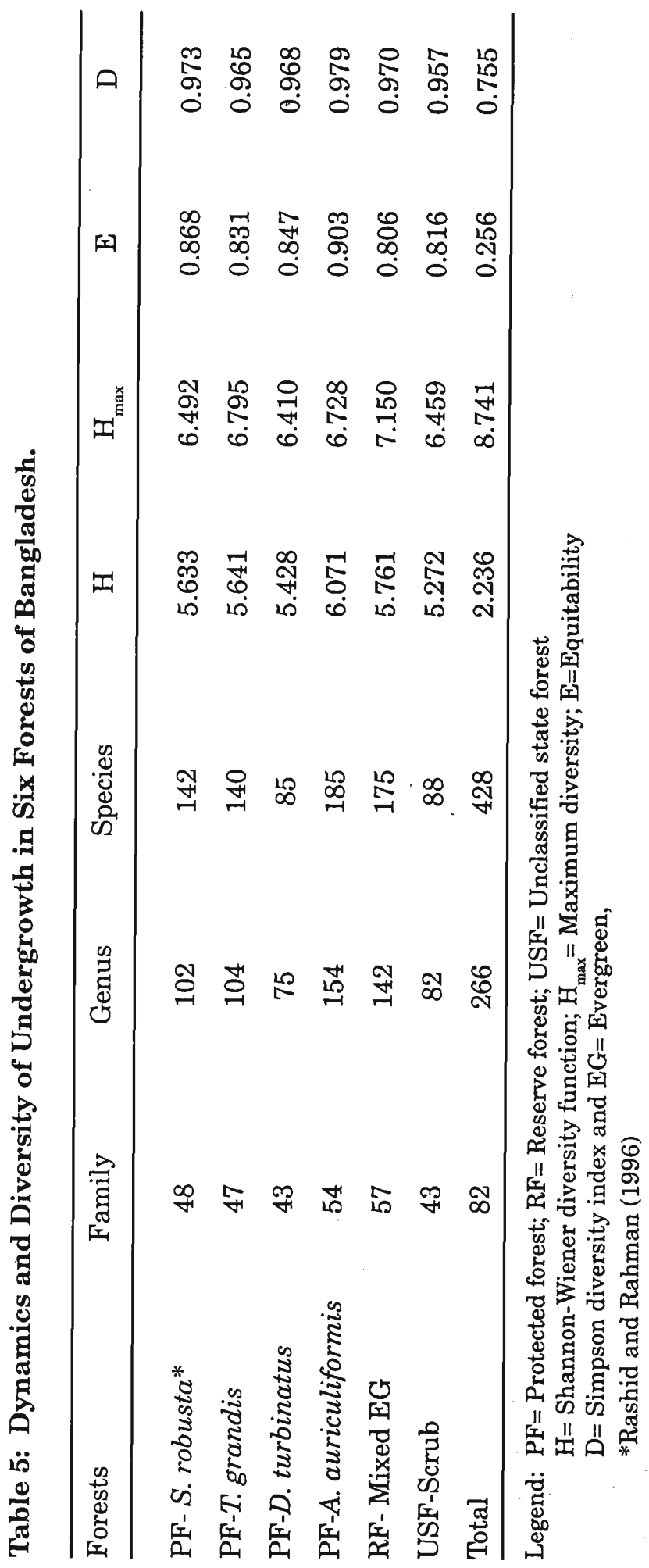


Commelinaceae, Dioscoreaceae and Zingiberaceae. The results as shown in Table 5 , also exhibit that the value of Shannon-Wiener species diversity $(\mathrm{H})$ was highest (6.071) in evergreen forests (Acacia auriculiformis-PF), but maximum species diversity was found in deciduous forests (Tectona grandis-PF). Equitability value was maximum (0.903) in evergreen forests (Acacia auriculiformis-PF). The average value of $\mathrm{H}, \mathrm{H}_{\max }, \mathrm{E}$ and $\mathrm{D}$ for six forests was found in the range of 2.236, 8.741, 0.256 and 0.755 respectively. Therefore, it is assumed that the nature of forests as well as the mode of protection of the undergrowth vegetation could enhance species diversity.

The undergrowth plant species of the forests have been treated as an important issue in the conservation and quality control of soil as well as of standing vegetation. In the present study it was attempted to assess the constant stock of various undergrowth of different forests of varying nature in Bangladesh. It was found that there was a clear fluctuation of undergrowth in different forests throughout the year. In most cases, the maximum number of undergrowth species occurred in JuneJuly, and the minimum number in December-January. It was also observed that a number of biotic (viz., encroachment, indiscriminate logging and extraction, clearing of forest cover, repeated weeding, leaf litter collection, cattle grazing, fuelwood collection etc.) and abiotic (viz., erosion, landslides, firing, drought etc.) factors were responsible for the degradation of plant diversity in different forests of Bangladesh. It is assumed that there is a great threat of decreasing undergrowth species in the forests studied, because of continuous interference from local people. Mainly during the winter/dry season every year, fallen leaves, herbaceous and shrubby plants are collected by local people to meet their daily needs. On the other hand, in some cases, the fallen leaves and undergrowth are also burnt by firing and the ashes are washed down by rainwater. Therefore, the organic matter content and nutrients cannot be restored to the forest floor soil, and thus the productivity of these forest ecosystems has been decreasing day by day. ${ }^{2}$

\section{Conclusion}

- A total of 428 undergrowth species were collected and recorded. These 428 species belonged to 82 families, consisting of 266 genera. Families such as Fabaceae, Euphorbiaceae, Poaceae and Commelinaceae were found to have the maximum importance value per cent.

- Undergrowth species consisted of 33 large trees, 57 small trees, 45 shrubs, 72 under shrubs, 151 herbs, 39 climbers, 15 grasses, 9 sedges and 7 ferns. Life form analysis found the plant climate to be a nano-microphaenerophytic one.

- Dynamics and diversity of species of undergrowth of six forests comprising four protected, one reserve and one unclassified state forests were found to belong to the categories of deciduous, semi-evergreen and evergreen forests, revealing that all the forests still contain higher species diversity and diver- 
sity index. Of course, there was a variation in diversity amongst the forests but that variation was not so prominent.

- Prevailing biotic and abiotic interferences may bring an alarming change in these forest ecosystems, as well as in the genetic resource-gene pool of existing phytodiversity.

- Physico-chemical properties of soils of all forests were more or less the same. The average value of all parameters of soil indicate that the soils of all forest floors were of sandy loam to sandy clay loam, poor in nutrients, and acidic in nature with an average $\mathrm{pH}$ value of 5.26 .

\section{The following attempts should therefore be taken for future sustainability of the existing undergrowth flora:}

- Similar intensive as well as extensive investigations should be carried out in most forests of Bangladesh.

- Illegal felling, cutting, weeding, firing etc. of forests and forest floors should be prohibited in order to enhance natural regeneration of both standing crops and undergrowth.

- Genetic resource-gene pool of undergrowth of all forests consisting of medicinal plants, leguminous and nitrogen fixers, soil covering plants, soil binding fodder, forage and green manure should be conserved for wildlife as well as for domestic use. A number of undergrowth species of forests are commercially important which may be grown as agro-forest products.

\section{Acknowledgement}

The authors are grateful to the staff of National Herbarium, Dhaka, and also to the staff of Bangladesh Forest Research Institute, Chittagong, for their sincere help in the identification of some plant species, and to the Forest Department for their cooperation during the study period. The authors are also indebted to Prof. A. K. M. Nazrul-Islam, Department of Botany, University of Dhaka, for his generous help in analyzing the species diversity.

\section{References}

1 Black C.A. (1964). Methods of Soil Analysis. Amer. Soc. Agron., Medison, Wisconsin, USDA,USA. 
2 Chowdhury M.A.M., Huda M.K. \& Islam A.S.M.T.(2000). Phytodiversity of Dipterocarpus turbinatus Gartn.F. (Garjan) undergrowths at Dulahazara Garjan Forest, Cox's Bazaar, Bangladesh. The Ind. For.,126(6): 674-684.

3 Curtis J. T. (1965). Plant Ecology Work Book. Minneapolis : Burgess Publishing Company pp 306.

4 Das S. (1980). Dipterocarp Forest of Bangladesh and their Management. Bano Bigyan Patrika, 9 (1 \& 2): 71-86.

5 Gain P. (1998). Forests-Bangladesh Environment: Facing the $21^{\text {st }}$ Century, Ed. Phillip Gain and published by SEHD, Dhanmondi, Dhaka pp. 496.

6 Jackson M. L. (1965). Soil Chemical Analysis. Prentice-Hall Inc. Englewood, Cliff., N. J., U. S. A., pp. 496.

$7 \quad$ Krebs C. J. (1972). Ecology: The Experimental Analyses of Distribution and Abundance. $2^{\text {nd }}$ Edn., Harper International, N.Y., pp. 678.

8 Lloyd M. \& R. J. Ghelardi (1964). A Table for Calculating the Equitability Components of Species Diversity. J. Anim. Ecol., 33: 217-225.

9 Raunkaier C. (1934). The Life Form of Plants and Statistical Plant Geography. Clarendon Press, Oxford, UK., pp.360.

10 Simpson E. H. (1949). Measurement of Diversity. Nature, 163-688.

11 USDA (1951). Soil Survey Manual, Agric Handbook No. 18. USDA, Washington.

12 Walkley A. \& Black C.A. (1934). An Examination of the Detjareff Method for Determining Soil Organic Matter and a Proposed Modification of the Chromic Acid Titration Method. Soil Sci., 37: 29-34. 